\title{
Influence of Leachate Matrix on Oxidation Performance of Ozonation and AOPs
}

\author{
Su-Huan Kow ${ }^{1 D}$, Muhammad Ridwan Fahmi 1,*(D), Che Zulzikrami Azner Abidin ${ }^{1}$, Najihah Abdul \\ Rashid $^{1}$ (D), Naimah Ibrahim ${ }^{1}$ (D), Abdul Haqi Ibrahim ${ }^{1}$ (D), Soon-An Ong ${ }^{\text {(DD , }}$ \\ Edza Aria Wikurendra 2 (D), Dwi Handayani ${ }^{2}$ (D) \\ 1 Water Research and Environmental Sustainability Growth (WAREG), Faculty of Civil Engineering Technology, \\ Universiti Malaysia Perlis, Pusat Pengajian Jejawi 3, Arau (02600) Perlis, Malaysia \\ 2 Department of Public Health, Universitas Nahdlatul Ulama Surabaya, 60237 Surabaya, Indonesia \\ * Correspondence: drfahmi@unimap.edu.my
}

Scopus Author ID 57219024467

Received: 5.10.2021; Revised: 20.11.2021; Accepted: 24.11.2021; Published: 4.12.2021

\begin{abstract}
Landfill leachate is a critical environmental issue that should be adequately treated to prevent it from spreading to the environment. This study explored the influence of raw leachate matrix and treated leachate matrix on $\mathrm{O} 3, \mathrm{O} 3 / \mathrm{H} 2 \mathrm{O} 2$, and $\mathrm{O} 3 / \mathrm{PS}$ performance. $\mathrm{O}_{3}$ and AOPs were conducted in a laboratory-scale batch reactor. The findings showed the degradation of p-cresol, COD, and humic substances was much slower in treated leachate matrix than in raw leachate matrix. However, color was found easier to remove in treated leachate. The results revealed a synergic effect between molecular $\mathrm{O}_{3}$ and dissolved organic matter in the raw leachate as the $\mathrm{O}_{3}$ performance was enhanced in the presence of raw leachate matrix, except for color removal. The highest degradation of more than $90 \%$ was achieved in $\mathrm{O}_{3} / \mathrm{H}_{2} \mathrm{O}_{2}$ to remove COD, p-cresol, and humic substances, although it is the most affected by the leachate matrix. This study provides vital insight into the notable performance of $\mathrm{O}_{3} / \mathrm{PS}$ in color removal regardless of the influence of leachate matrix, suggesting that the sulfate radical-induced oxidation outperformed $\mathrm{O}_{3}$ and $\mathrm{O}_{3} / \mathrm{H}_{2} \mathrm{O}_{2}$ in reducing nitrogen-containing compounds.
\end{abstract}

Keywords: leachate; hydroxyl radical; ozonation; p-cresol; sulfate radical.

(c) 2021 by the authors. This article is an open-access article distributed under the terms and conditions of the Creative Commons Attribution (CC BY) license (https://creativecommons.org/licenses/by/4.0/).

\section{Introduction}

Landfill leachate is a major environmental issue globally as it could pose a great risk to drinking water sources, human health, and the ecosystem [1]. It is highly polluted wastewater generated during the waste decomposition process in landfill systems [2,3] and is often comprised of a high amount of recalcitrant organic compounds and ammoniacal nitrogen [4]. In particular, the four major categories of pollutants in leachate are small molecular biodegradable organic and large molecular recalcitrant organic matter, xenobiotic organic compounds (XOCs), heavy metals, as well as inorganic macro components [5]. XOCs, especially phenolic compounds, are contaminants of emerging concern and have been reported predominant in landfill leachate [6]. Moreover, Masoner et al. [7] reported p-cresol, bisphenol A, and phenol contributed $70 \%-83 \%$ of the total measured concentration of contaminants of emerging concern in landfill leachate. In addition to that, the high ammonia content of leachate has also been reported as a critical long-term pollutant [8] which could cause eutrophication in surface water and inhibit cell proliferation in living organisms [9]. Due to its highly heterogeneous nature, landfill leachate generally consists of indolic compounds such as 3- 
methyl-indole and 2,3-dihydro-1H-indole-1-carboxaldehyde that can maximize the adverse effect contamination to the surrounding ecosystem [10]. Therefore, landfill leachate treatment is essential before discharges to open water to prevent those contaminants from spreading to the surrounding areas.

Ozonation $\left(\mathrm{O}_{3}\right)$ and advanced oxidation processes (AOPs) have been proposed as an alternative treatment for wastewater, including landfill leachate [11-13]. The high oxidation power of molecular $\mathrm{O}_{3}\left(\mathrm{E}_{\mathrm{h}}=2.07 \mathrm{~V}\right)$ and radicals produced in AOPs, e.g., $\mathrm{OH}^{*}\left(\mathrm{E}_{\mathrm{h}}=2.8 \mathrm{~V}\right)$ and $\mathrm{SO}_{4}{ }^{-}\left(\mathrm{E}_{\mathrm{h}}=2.7 \mathrm{~V}\right)$, makes it possible to degrade a wide range of organic pollutants, including those persist to biodegradation. Currently, many studies have demonstrated that $\mathrm{O}_{3}$ and AOPs are very efficient in the oxidation of phenolic compounds [14-16], pharmaceuticals [17,18], pesticides [19], azo dyes [20], and indolic compounds [21]. Besides, various researchers have also studied the performance of $\mathrm{O}_{3}$ and AOPs in removing COD, ammonia and improving the biodegradability of landfill leachate [22-24]. Their findings showed $\mathrm{O}_{3}$ and AOPs capable of reducing COD and improving the biodegradability of landfill leachate; however, only treatment including SO4•- is effective in reducing ammonia.

The current treatment practice using $\mathrm{O}_{3}$ and AOPs is often viewed as efficient in removing contaminants. However, the major consideration needed for the process's application in industrials is the interferences of wastewater matrix. There are limited studies on the influence of leachate matrix on the performance of $\mathrm{O}_{3}$, ozone combined with hydrogen peroxide $\left(\mathrm{O}_{3} / \mathrm{H}_{2} \mathrm{O}_{2}\right)$, and ozone combined with persulphate $\left(\mathrm{O}_{3} / \mathrm{PS}\right)$ p-cresol oxidation. Furthermore, most of the published works focus on the $\mathrm{O}_{3}$ and AOPs performance in oxidizing solely organic compounds; or removing refractory organics and ammonia in landfill leachate. This leads to the need to investigate p-cresol oxidation by $\mathrm{O}_{3}, \mathrm{O}_{3} / \mathrm{H}_{2} \mathrm{O}_{2}$, and $\mathrm{O}_{3} / \mathrm{PS}$ in the presence of a leachate matrix. In addition to that, the performance of methods studied was also compared in terms of reduction in organic substances concentration, humic substances, and color. This study also expected to present that the oxidants species involved in methods studied react differently with complex constituents in leachate, consequently leading to the differences in degradation performance.

\section{Materials and Methods}

The chemicals and materials were given in a previous study [25]. All chemicals were used as per received without further purification.

Leachate samples were obtained from Rimba Mas sanitary landfill in Perlis-Malaysia, delivered to the laboratory on the same day, and kept at $4{ }^{\circ} \mathrm{C}$ until use. The existing leachate treatment in sequence flow comprised lamella clarifier, sequencing batch reactor (SBR), and dissolved air flotation (DAF) system. The leachate samples used in this study were collected from raw leachate pond and SBR pond. The characteristics of raw leachate and treated leachate were assessed for $\mathrm{pH}, \mathrm{COD}$, ORP, total solid (TS), total dissolved solids (TDS), and UV-Vis optical density at $254 \mathrm{~nm}$ for humic substances including aromatic and unsaturated compounds [26] and $410 \mathrm{~nm}$ for color [27].

A laboratory-scale ozonation reactor was used in this study, as illustrated in Figure 1. An ozone generator (A2Z1GLab ozone generator, A2Z Ozone, USA) with $\mathrm{O}_{3}$ output of $1.0 \mathrm{~g}$ $\mathrm{O}_{3} / \mathrm{h}$ was used to generate and supply $\mathrm{O}_{3}$ gas continuously at a flow rate of $1.0 \mathrm{~L} \mathrm{O}_{3} / \mathrm{min}$ into the reaction medium through a bubble diffuser. Throughout the experiment, the reaction medium was stirred using a magnetic stirrer, and the medium temperature was maintained by using a bath circulator (WiseCircu WCH-8 high-temperature bath circulators, Witeg, 
Germany). For $\mathrm{O}_{3} / \mathrm{H}_{2} \mathrm{O}_{2}$ and $\mathrm{O}_{3} / \mathrm{PS}, 1.0 \mathrm{mM}$ of $\mathrm{H}_{2} \mathrm{O}_{2}$ and persulfate were added into the reaction medium before ozonation.

$\mathrm{O}_{3}$ and AOPs experiments were conducted in pre-determined optimum operating conditions (1.0 $\mathrm{L} \mathrm{O}_{3} / \mathrm{min}, 1.0 \mathrm{mM}$ of $\mathrm{H}_{2} \mathrm{O}_{2}$ or persulfate, $\mathrm{pH} 11$, and $30{ }^{\circ} \mathrm{C}$ ) in previous work without the influence of wastewater matrix [25]. In prior experiments, the same amount of COD loading $\left(\mathrm{L}_{\mathrm{COD}}=25 \mathrm{mg} / \mathrm{L}\right)$ from raw leachate and treated leachate were added into $\mathrm{p}$ cresol samples to investigate the effect of leachate matrix towards the performance of $\mathrm{O}_{3}$, $\mathrm{O}_{3} / \mathrm{H}_{2} \mathrm{O}_{2}$, and $\mathrm{O}_{3} / \mathrm{PS}$ in p-cresol oxidation.

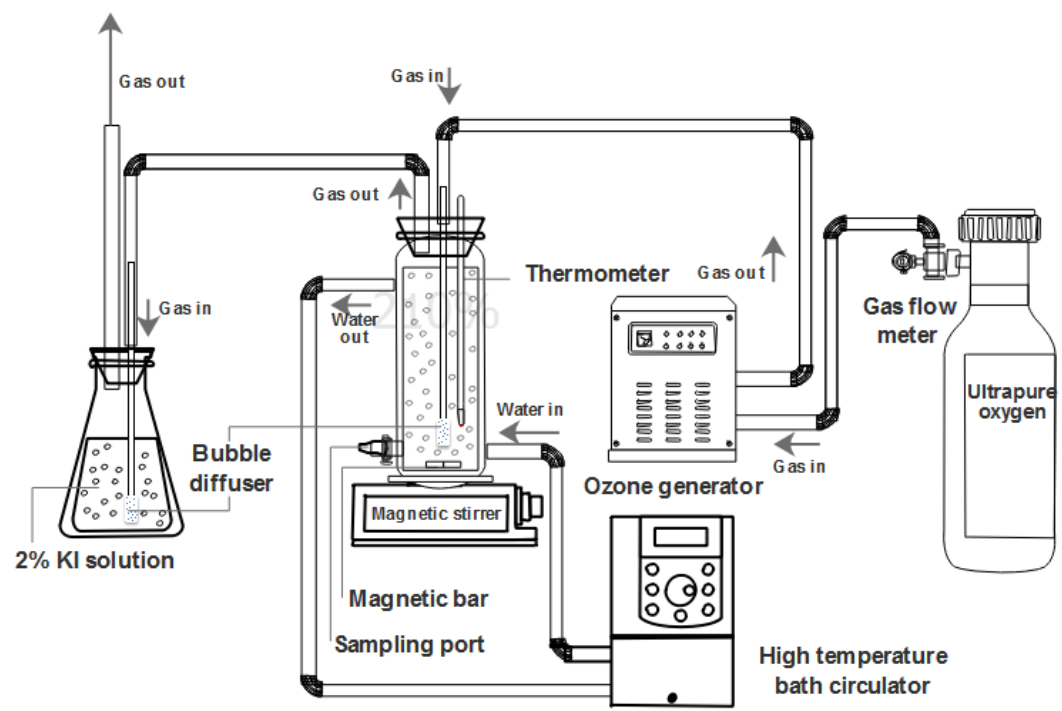

Figure 1. Experimental setup for $\mathrm{O}_{3}$ and AOPs experiments.

The characteristic absorption peaks correspond to p-cresol $\left(\mathrm{UV}_{295}\right)$, humic substances $\left(\mathrm{UV}_{254}\right)$ [26,28], and color $\left(\mathrm{UV}_{410}\right)$ [27] were measured by using UV-Vis spectrophotometer (ME-UV1200 UV-Vis spectrophotometer, MesuLab, China). The reduction in organic substances concentration was determined based on COD, following Standard Method 5220D [29]. The degradation of p-cresol, COD, humic substances, and color was evaluated by using the ratio of absorbance before and after treatment $\left(\mathrm{A}_{t}\left(\mathrm{~A}_{0}\right)^{-1}\right)$ at their respective characteristic absorption peak. The higher the $\mathrm{A}_{\mathrm{t}}\left(\mathrm{A}_{0}\right)^{-1}$ ratio indicates, the lower the degradation efficiencies for the corresponding parameters.

\section{Results and Discussion}

\subsection{Characterization of leachate samples.}

The characteristics of raw leachate and treated leachate can be found in Table 1. The raw leachate sample was dark brown, had a $\mathrm{pH}$ of 8.1, average COD value of $2090 \mathrm{mg} / \mathrm{L}$, negative ORP of $-214.4 \mathrm{mV}$, and TS and TDS of $8415 \mathrm{mg} / \mathrm{L}$ and $7170 \mathrm{mg} / \mathrm{L}$, respectively. The negative ORP value in raw leachate is common and could assign to the lack of oxygen in the landfill system [30]. The treated leachate sample was in light brown and had the same $\mathrm{pH}$ as raw leachate. All of the values of the parameters in treated leachate were lower, except for ORP, which could attribute to the oxygen supplied into the leachate in SBR treatment.

Table 1. Characteristics of raw leachate and treated leachate.

\begin{tabular}{l|c|c|c} 
Parameter & Unit & Raw leachate & Treated leachate \\
\hline pH & - & 8.1 & 8.1 \\
\hline COD & $\mathrm{mg} / \mathrm{L}$ & 2090 & 880 \\
\hline ORP & $\mathrm{mV}$ & -214.4 & 133.3
\end{tabular}




\begin{tabular}{l|c|c|c} 
Parameter & Unit & Raw leachate & Treated leachate \\
\hline TS & $\mathrm{mg} / \mathrm{L}$ & 8415 & 6865 \\
\hline TDS & $\mathrm{mg} / \mathrm{L}$ & 7170 & 6325 \\
\hline $\mathbf{U V}_{\mathbf{2 5 4}}$ & $\mathrm{Au}$ & 14.32 & 11.30 \\
\hline $\mathbf{U V}_{\mathbf{4 1 0}}$ & $\mathrm{Au}$ & 2.83 & 2.42
\end{tabular}

The characteristics of UV-Vis absorption spectra of $50 \mathrm{mg} / \mathrm{L}$ of $\mathrm{p}$-cresol at $\mathrm{pH} 11$ and both leachate samples with dilution factor (df) of 25 were illustrated in Figure 2. The high absorption intensity at $\mathrm{UV}_{254}$ of raw leachate and treated leachate indicated that the humic substances in the leachate were complex and high in aromaticity [31]; therefore could not be removed easily by SBR treatment. Besides, the absorption band at $200-240 \mathrm{~nm}$ in the UVVis absorption spectra of the treated leachate sample suggests some of the complex pollutants in raw leachate were biodegraded and transformed to polycyclic aromatic compounds macromolecular organic matter [32].

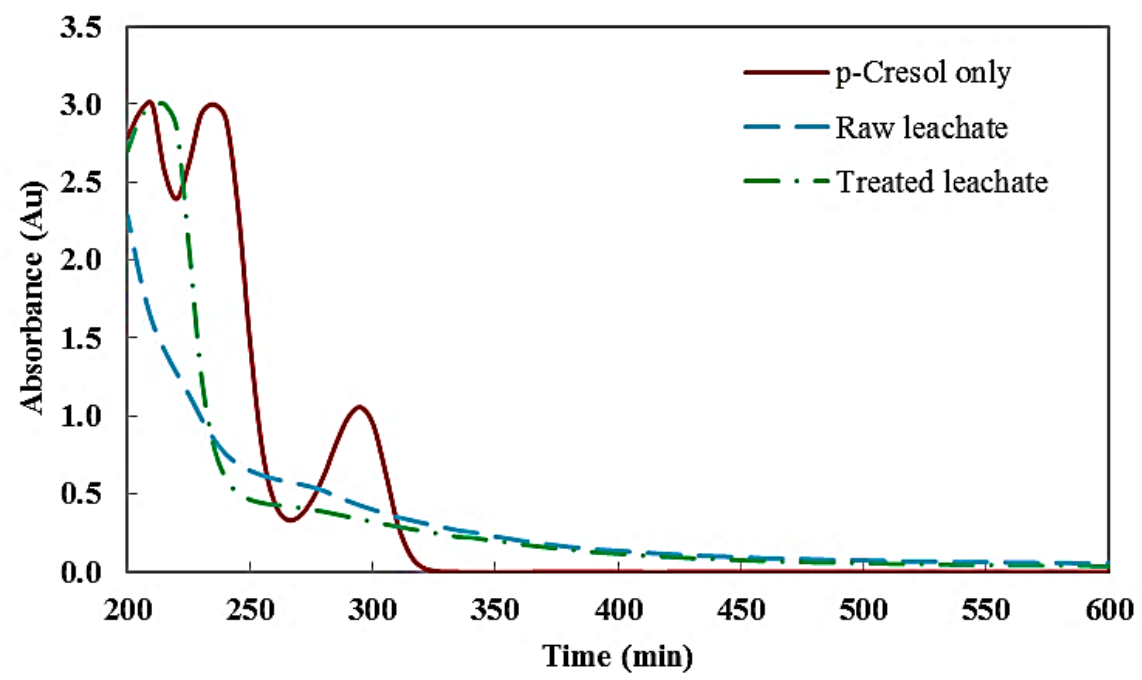

Figure 2. Characteristics of UV-Vis absorption spectra of p-cresol (50mg/L, pH 11), raw leachate (df: 25), and SBR leachate (df: 25).

\subsection{Effect of $L_{C O D}$ in raw leachate and treated leachate on $p$-cresol degradation by $\mathrm{O}_{3}$ and} AOPs.

Figure 3 depicts the degradation of p-cresol by $\mathrm{O}_{3}, \mathrm{O}_{3} / \mathrm{H}_{2} \mathrm{O}_{2}$, and $\mathrm{O}_{3} / \mathrm{PS}$ under the influence of the leachate matrix. The $\mathrm{A}_{295, \mathrm{t}}\left(\mathrm{A}_{295,0}\right)^{-1}$ ratio, which corresponds to p-cresol degradation efficiency, clearly demonstrated that the methods studied were more affected in the presence of $\mathrm{L}_{\mathrm{COD}}$ in treated leachate than in raw leachate. In particular, $\mathrm{O}_{3} / \mathrm{H}_{2} \mathrm{O}_{2}$ was the most affected as the p-cresol degradation is 3.8-fold slower than $\mathrm{O}_{3} / \mathrm{PS}$ (2.0-fold) and $\mathrm{O}_{3}$ (1.7fold). This is due to the nonselective nature of $\mathrm{OH}^{*}[33,34]$, therefore easier to be scavenged by background constituents in leachate as compared to molecular $\mathrm{O}_{3}$ and $\mathrm{SO}_{4}{ }^{*}$. Other than that, the higher $\operatorname{COD}_{\mathrm{t}}\left(\mathrm{COD}_{0}\right)^{-1}$ and $\mathrm{A}_{254, \mathrm{t}}\left(\mathrm{A}_{254,0}\right)^{-1}$ ratios (Table 2) in p-cresol and treated leachate mixture indicate the degradation efficiencies for COD and humic substance were lower. This finding agrees with the published works by Kamenev et al. [35], where the treatment efficiency of post-ozonation treatment is lower than pre-ozonation treatment with the same $\mathrm{O}_{3}$ dosage applied. This is probably due to the altering of residues biogenic compounds [36] and also the biodegradation products from pre-biological treatment. Furthermore, Lovato and co-workers [28] also came out with a similar conclusion in which the inhibition of degradation products formed was found to be maximized in treated leachate. 

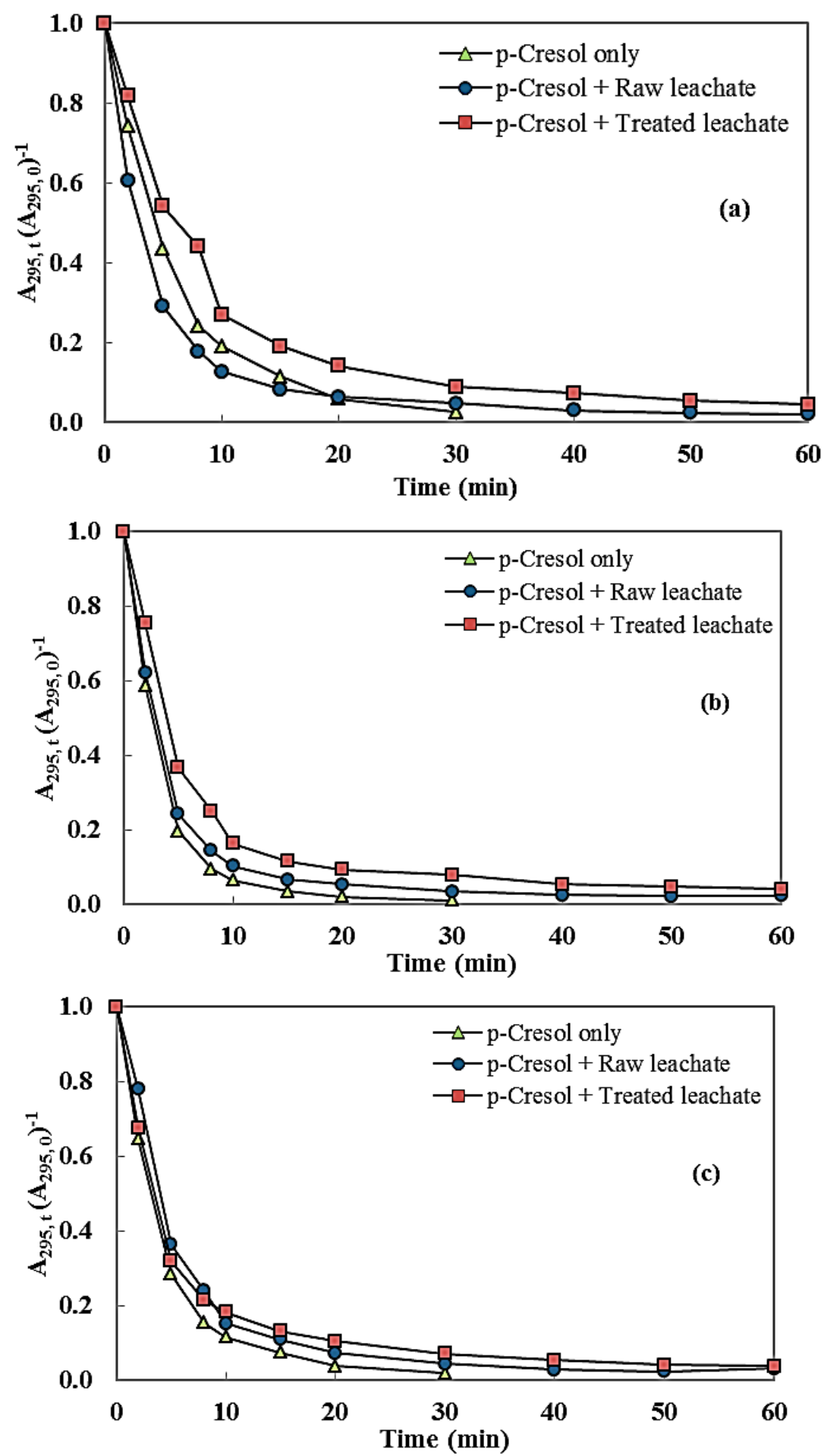

Figure 3. Degradation of p-cresol in (a) $\mathrm{O}_{3}$, (b) $\mathrm{O}_{3} / \mathrm{H}_{2} \mathrm{O}_{2}$, and (c) $\mathrm{O}_{3} / \mathrm{PS}$ in the presence of LCD in leachate samples. Experimental conditions: $50 \mathrm{mg} / \mathrm{L}$ of p-cresol $\left(\mathrm{COD}_{0}=107.3 \pm 3.5 \mathrm{mg} / \mathrm{L}\right)$ and 25 $\mathrm{mg} / \mathrm{L}$ of $\mathrm{L}_{\mathrm{COD}}$ in leachate samples.

Among these factors, the lower $\mathrm{A}_{410, \mathrm{t}}\left(\mathrm{A}_{410,0}\right)^{-1}$ values in $\mathrm{p}$-cresol and treated leachate mixture suggested that color was easier to remove in treated leachate than in raw leachate. This is probably due to the lower content of humic substances present in the leachate after SBR treatment (Table 1). This study also revealed that the degradation of $\mathrm{p}$-cresol by $\mathrm{O}_{3}$ was enhanced in the presence of $\mathrm{L}_{\mathrm{COD}}$ in raw leachate than in p-cresol only samples. The possible explanation is that the reactions between molecular $\mathrm{O}_{3}$ and dissolved organic matter (DOM) in the raw leachate matrix have a synergic effect in the p-cresol oxidation. This can be supported by Ghazi et al. [37], in which the authors stated that DOM could react with $\mathrm{O}_{3}$ to produce $\mathrm{OH}^{*}$. 
Figure 4 (a) and Figure 4 (b) illustrate the evolution of UV-Vis absorption spectra of pcresol degradation by $\mathrm{O}_{3}$ and AOPs in the presence of a leachate matrix. In the oxidation of $\mathrm{p}$ cresol and raw leachate mixture, the absorbance peak of p-cresol at $\mathrm{UV}_{295}$ decreases abruptly from 1.115 to 0.384 in $\mathrm{O}_{3} / \mathrm{PS}, 0.331$ in $\mathrm{O}_{3}$, and 0.271 in $\mathrm{O}_{3} / \mathrm{H}_{2} \mathrm{O}_{2}$ within merely five minutes of treatment. Whereas five-minute treatment of $\mathrm{p}$-cresol and treated leachate reduces the initial $\mathrm{A}_{295}$ value (1.236) to $0.677,0.449$, and 0.388 for $\mathrm{O}_{3}, \mathrm{O}_{3} / \mathrm{H}_{2} \mathrm{O}_{2}$, and $\mathrm{O}_{3} / \mathrm{PS}$, respectively. Through further oxidation, the final $\mathrm{A}_{295}$ values achieved were $0.028 \pm 0.005$ in p-cresol and raw leachate treatment, and the final $\mathrm{A}_{295}$ values achieved after 60 min were within $0.051 \pm$ 0.005 in p-cresol and treated leachate treatment. These indicated $\mathrm{O}_{3}, \mathrm{O}_{3} / \mathrm{H}_{2} \mathrm{O}_{2}$, and $\mathrm{O}_{3} / \mathrm{PS}$ are able to degrade p-cresol effectively under the influence of leachate matrix, and the matrix in treated leachate has a greater influence on the performance of methods studied. Other than that, the values $\mathrm{A}_{253} / \mathrm{A}_{203}$ and $\mathrm{A}_{250} / \mathrm{A}_{365}$ were also used as indicators for the amount substituent groups of organic compounds, including carbonyl, carboxyl, esters, and hydroxyl groups; as well as the extent of humification in the samples [31]. The $\mathrm{A}_{253} / \mathrm{A}_{203}$ and $\mathrm{A}_{250} / \mathrm{A}_{365}$ in the $\mathrm{p}$ cresol and raw leachate were $0.428 \pm 0.003$ and $30.008 \pm 2.656$; while in the p-cresol and treated leachate were $0.477 \pm 0.020$ and $14.314 \pm 1.507$. After treatment, the $A_{253} / A_{203}$ value decreased to $0.033-0.055$, implying the substituent groups of organic compounds in the sample were degraded. Besides, the lower $\mathrm{A}_{250} / \mathrm{A}_{365}$ values compared to the initial value suggest that the large molecular humic substances were degraded to fulvic acid, resulting in the increment in humification in the treated samples [32]. Similar trends were also observed in the oxidation of $\mathrm{p}$-cresol and treated leachate samples. However, the $\mathrm{A}_{253} / \mathrm{A}_{203}$ values were generally higher compared to those in treated samples in the p-cresol and raw leachate treatment (Table 2). This could be ascribed to the interference of humic substances in the treated leachate matrix because the number of humic substances in treated leachate was doubled compared to raw leachate.
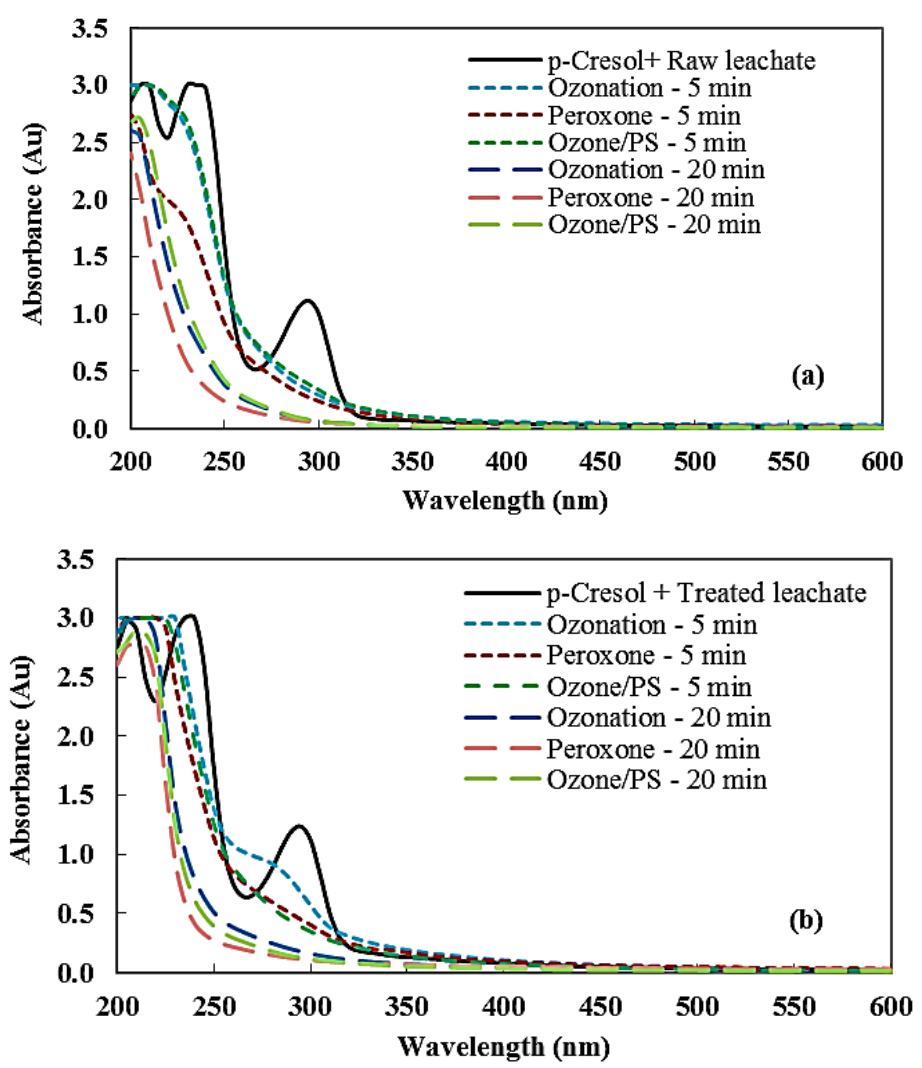

Figure 4. Evolution of UV-Vis absorption spectra of p-cresol degradation by $\mathrm{O}_{3} \mathrm{O}_{3} / \mathrm{H}_{2} \mathrm{O}_{2}$ and $\mathrm{O}_{3} / \mathrm{PS}$ in the presence of (a) raw leachate and (b) treated leachate matrix. 
Table 2. Degradation performance of methods studied under the influence of $\mathrm{L}_{\mathrm{COD}}$ in leachate samples.

\begin{tabular}{|c|c|c|c|}
\hline Process/Parameter & $\begin{array}{c}\text { p-Cresol only } \\
\text { min) }\end{array}$ & $\begin{array}{c}\text { p-Cresol + Raw } \\
\text { leachate }(60 \mathrm{~min})\end{array}$ & $\begin{array}{c}\text { p-Cresol + Treated } \\
\text { leachate }(60 \text { min) }\end{array}$ \\
\hline \multicolumn{4}{|l|}{ Ozonation } \\
\hline $\operatorname{COD}_{t}\left(\mathrm{COD}_{0}\right)^{-1}$ & 0.350 & 0.351 & 0.393 \\
\hline$A_{295, t}\left(\mathbf{A}_{295,0}\right)$ & 0.026 & 0.020 & 0.045 \\
\hline$A_{254, t}\left(A_{254,0}\right)^{-1}$ & 0.063 & 0.082 & 0.110 \\
\hline$A_{410, t}\left(A_{410,0}\right)^{-1}$ & - & 0.303 & 0.254 \\
\hline $\mathbf{A}_{253} / \mathbf{A}_{203}$ & - & 0.033 & 0.051 \\
\hline $\mathbf{A}_{250} / \mathbf{A}_{365}$ & - & 7.583 & 5.784 \\
\hline \multicolumn{4}{|l|}{ Peroxone } \\
\hline $\operatorname{COD}_{t}\left(\mathrm{COD}_{0}\right)^{-1}$ & 0.185 & 0.223 & 0.262 \\
\hline$A_{295, t}\left(A_{295,0}\right)^{-1}$ & 0.011 & 0.024 & 0.042 \\
\hline$A_{254, t}\left(A_{254,0}\right)^{-1}$ & 0.043 & 0.089 & 0.096 \\
\hline $\mathbf{A}_{410, \mathrm{t}}\left(\mathbf{A}_{410,0}\right)^{-1}$ & - & 0.539 & 0.416 \\
\hline $\mathbf{A}_{253} / \mathbf{A}_{203}$ & - & 0.039 & 0.046 \\
\hline $\mathbf{A}_{250} / \mathbf{A}_{365}$ & - & 0.267 & 2.996 \\
\hline \multicolumn{4}{|l|}{ Ozone/PS } \\
\hline $\operatorname{COD}_{t}\left(\mathrm{COD}_{0}\right)^{-1}$ & 0.273 & 0.423 & 0.423 \\
\hline$A_{295, t}\left(A_{295,0}\right)^{-1}$ & 0.019 & 0.031 & 0.038 \\
\hline$A_{254, t}\left(A_{254,0}\right)^{-1}$ & 0.081 & 0.119 & 0.121 \\
\hline $\mathbf{A}_{410, \mathrm{t}}\left(\mathrm{A}_{410,0}\right)^{-1}$ & - & 0.489 & 0.116 \\
\hline $\mathbf{A}_{253} / \mathbf{A}_{203}$ & - & 0.055 & 0.054 \\
\hline $\mathbf{A}_{250} / \mathbf{A}_{365}$ & - & 8.003 & 10.200 \\
\hline
\end{tabular}

3.3. Performance comparison between $\mathrm{O}_{3}$ and $A O P$ s under the influence of raw leachate matrix and treated leachate matrix.

Figure 5 and Figure 6 present the performance comparison of $\mathrm{O}_{3}, \mathrm{O}_{3} / \mathrm{H}_{2} \mathrm{O}_{2}$, and $\mathrm{O}_{3} / \mathrm{PS}$ concerning the type of leachate samples. In both cases, $\mathrm{O}_{3} / \mathrm{H}_{2} \mathrm{O}_{2}$ is the most efficient in reducing COD, p-cresol, and humic substances under the influence of the leachate matrix despite it being the most affected by the leachate matrix as mentioned in the previous section.
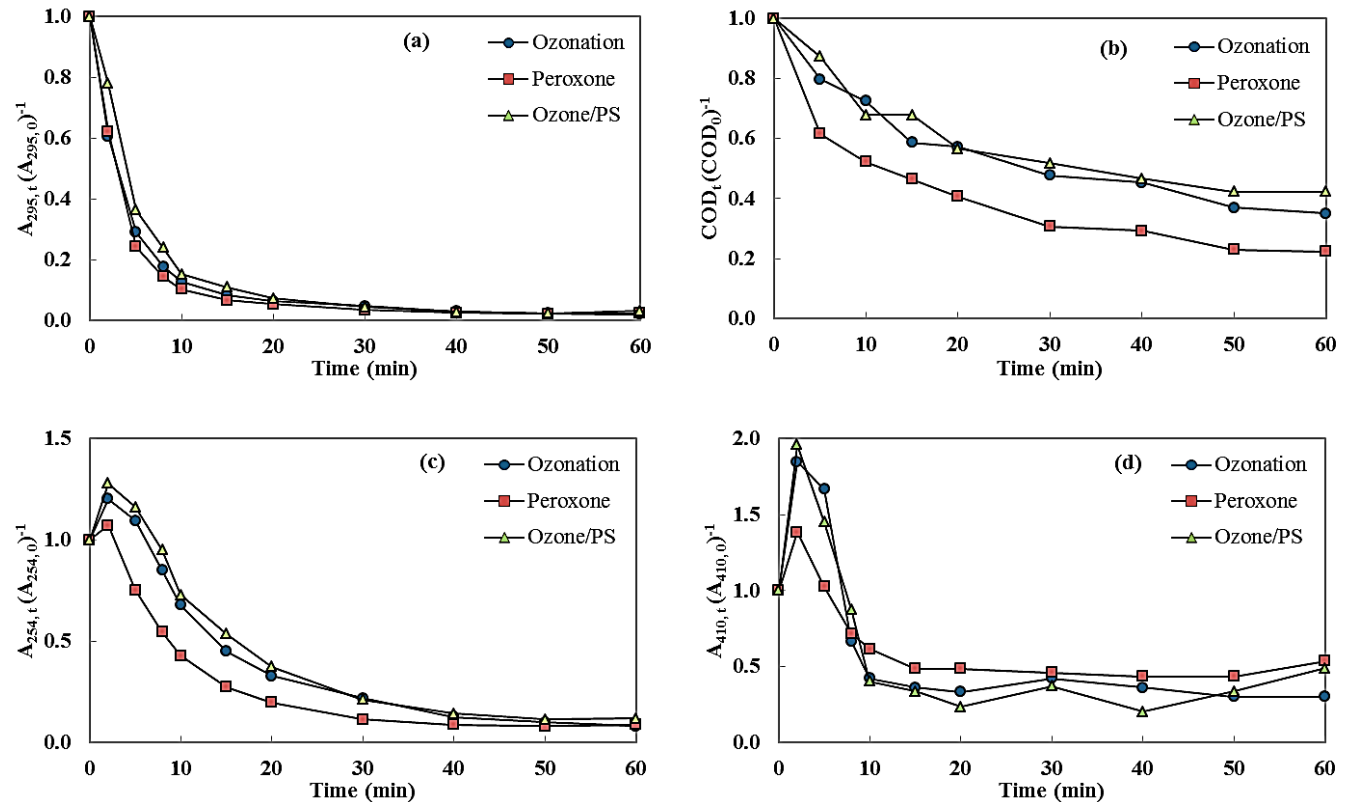

Figure 5. Performance comparison of methods studied in the removal of (a) p-cresol, (b) COD, (c) humic substances, and (d) color in the presence of raw leachate matrix. Experimental conditions: $50 \mathrm{mg} / \mathrm{L}$ of p-cresol $\left(\mathrm{COD}_{0}=107.3 \pm 3.5 \mathrm{mg} / \mathrm{L}\right)$ and $25 \mathrm{mg} / \mathrm{L}$ of $\mathrm{L}_{\mathrm{COD}}$ in leachate samples.

This could assign to the high production and high oxidation power of $\mathrm{OH}^{\bullet}$ at elevated $\mathrm{pH}$ in $\mathrm{O}_{3} / \mathrm{H}_{2} \mathrm{O}_{2}$. Besides, it was observed that $\mathrm{O}_{3}$ has a slightly better performance compared to $\mathrm{O}_{3} / \mathrm{PS}$ in the oxidation of $\mathrm{p}$-cresol in raw leachate. The enhancement in $\mathrm{O}_{3}$ performance may attribute to the synergic effect of reaction between molecular $\mathrm{O}_{3}$ and DOM presence in the raw leachate matrix. The synergic effect was not observed in $\mathrm{O}_{3} / \mathrm{H}_{2} \mathrm{O}_{2}$ and $\mathrm{O}_{3} / \mathrm{PS}$, probably due to 
the DOM having a scavenging effect on the $\mathrm{OH}^{\circ}$ produced in the AOPs. In fact, similar findings were also obtained in published work by Ghazi et al. [37] in which they reported that $\mathrm{O}_{3}$ performed better in bisphenol-A degradation in leachate compared to $\mathrm{O}_{3} / \mathrm{H}_{2} \mathrm{O}_{2}$ as high concentration of DOM scavenged $\mathrm{OH}^{*}$ and converted it to a less reactive superoxide radical $\left(\mathrm{O}_{2}{ }^{--}\right)$
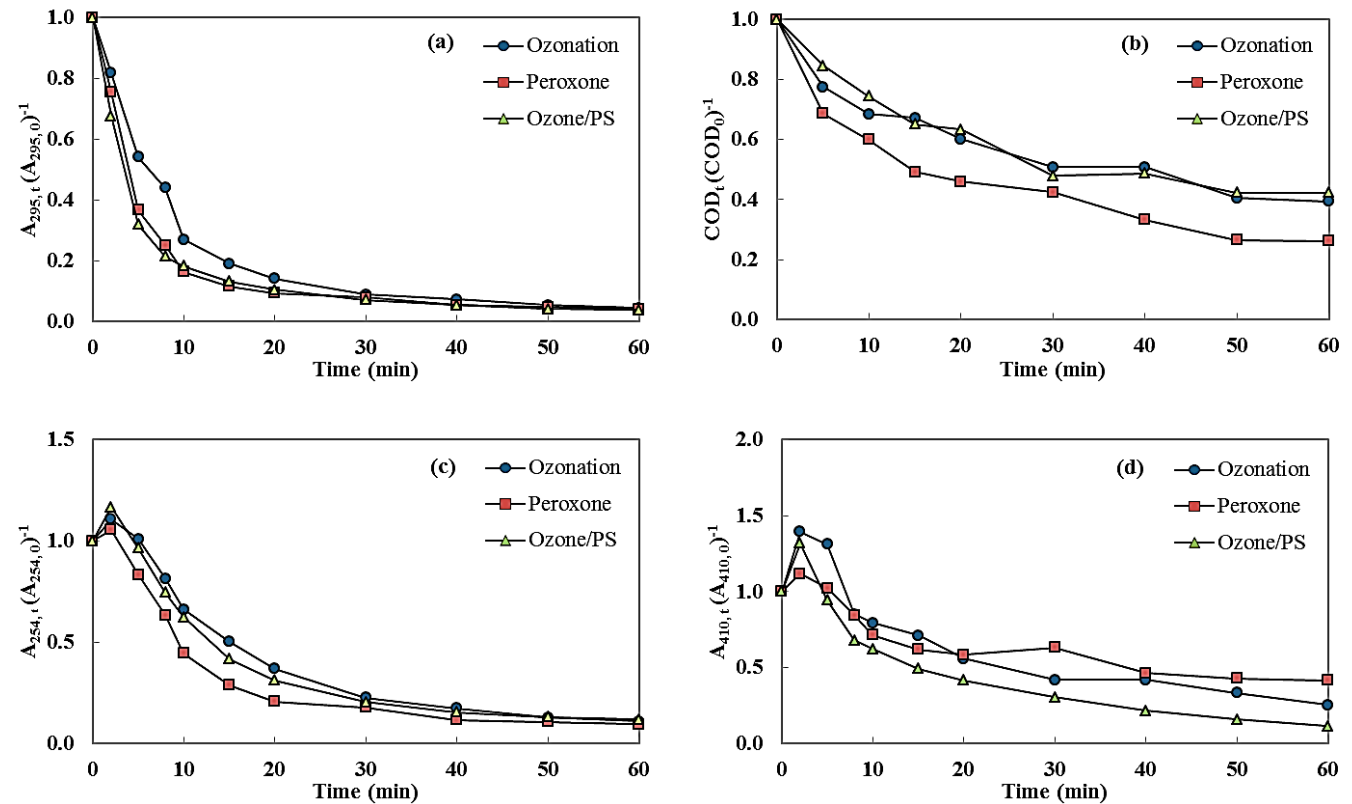

Figure 6. Performance comparison of methods studied in the removal of (a) p-cresol, (b) COD, (c) humic substances, and (d) color in the presence of treated leachate matrix. Experimental conditions: $50 \mathrm{mg} / \mathrm{L}$ of pcresol $\left(\mathrm{COD}_{0}=102.0 \pm 4.5 \mathrm{mg} / \mathrm{L}\right)$ and $25 \mathrm{mg} / \mathrm{L}$ of $\mathrm{L}_{\mathrm{COD}}$ in leachate samples.

In addition, Figure 5 and Figure 6 also show that $\mathrm{O}_{3} / \mathrm{PS}$ has notable efficiency for color removal regardless of the influence of the leachate matrix. This suggests that the $\mathrm{SO}_{4}{ }^{-}$induced oxidation in $\mathrm{O}_{3} / \mathrm{PS}$ is more effective in reducing the organic compounds contributed to color in leachate. In fact, a decolorization study by Razali et al. [20] also demonstrated that $\mathrm{O}_{3} / \mathrm{PS}$ is more effective in decolorization than $\mathrm{O}_{3}$. It is postulated that the organic compounds responsible for color were nitrogen-containing compounds [38], which lie along UV band at $275 \mathrm{~nm}$ (for aliphatic compounds) and the visible band at $350 \mathrm{~nm}$ (for aromatics) [39,40]. This is in concurrence with the fact that leachate samples comprise high nitrogen content [41] as ammonia nitrogen has no degradation route in landfills [42]. Furthermore, the deactivating nature of the nitrogen group towards electrophilic aromatic substitution (EAS) of the benzene ring might be the reason for the underperformance of $\mathrm{O}_{3}$ and $\mathrm{O}_{3} / \mathrm{H}_{2} \mathrm{O}_{2}$. This claim can also be supported by findings in published work by Deng et al. [43] and Abu Amr et al. [44] in which the authors reported that complete removal of ammonia was achieved only in treatment involving $\mathrm{SO}_{4}{ }^{\circ}$. This can attribute to the oxidation mechanism of molecular $\mathrm{O}_{3}$, and $\mathrm{OH}^{*}$ are mainly through EAS; while $\mathrm{SO}_{4}{ }^{-}$can oxidize contaminants through alternative mechanisms via a single electron transfer (SET) pathway [32, 45-52].

\section{Conclusions}

This study demonstrated that the performance of $\mathrm{O}_{3}, \mathrm{O}_{3} / \mathrm{H}_{2} \mathrm{O}_{2}$, and $\mathrm{O}_{3} / \mathrm{PS}$ was more affected by treated leachate matrix than raw leachate matrix for the reduction of COD, p-cresol, and humic substances; but contrasted for color removal. The synergic effect was found between molecular $\mathrm{O}_{3}$ and raw leachate matrix as the degradation of p-cresol enhanced in the presence 
of raw leachate matrix. $\mathrm{O}_{3} / \mathrm{H}_{2} \mathrm{O}_{2}$ attained the best overall degradation performance, although it is the most affected by the presence of the leachate matrix. However, the highest color removal was achieved in $\mathrm{O}_{3} / \mathrm{PS}$ regardless of the influence of the leachate matrix. The outperformance of $\mathrm{O}_{3} / \mathrm{PS}$ in color removal suggests that sulfate radical-induced oxidation might have greater potential in landfill leachate treatment considering the persistency of nitrogen-containing compounds in the leachate matrix. Nonetheless, the practical application of $\mathrm{O}_{3}$ and AOPs in leachate treatment depends on the treatment objective, i.e., preliminary treatment to degrade persistent organic compounds in leachate before biological treatment; as a secondary or tertiary treatment to remove micropollutants remained from previous treatment.

\section{Funding}

The authors would like to thanks for the funding support from the Ministry of Higher Education Malaysia (Grant Number: FRGS/2/2013/TK05/UNIMAP/02/3).

\section{Acknowledgments}

The authors would like to acknowledge the support from the SWCorp Malaysia and the Faculty of Civil Engineering Technology, Universiti Malaysia Perlis, Malaysia.

\section{Conflicts of Interest}

The authors declare no conflict of interest.

\section{References}

1. Ololade, O.O.; Mavimbela, S.; Oke, S.A.; Makhadi, R. Impact of leachate from northern landfill site in bloemfontein on water and soil quality: implications for water and food security. Sustainability 2019, 11, https://doi.org/10.3390/su11154238.

2. Ayash, M.M.A.; Abu-Amr, S.S.; Alkarkhi, A.F.M.; Zulkifli, M.; Mahmud, M.N. Evaluation of landfill leachate treatment system using multivariate analysis. Desalin Water Treat 2021, 229, 194-205, https://doi.org/10.5004/dwt.2021.27378.

3. Lebron, Y.A.R.; Moreira, V.R.; Brasil, Y.L.; Silva, A.F.R.; Santos, L.V.d.S.; Lange, L.C.; Amaral, M.C.S. A survey on experiences in leachate treatment: Common practices, differences worldwide and future perspectives. J Environ Manage 2021, 288, https://doi.org/10.1016/j.jenvman.2021.112475.

4. Yong, Z.J.; Bashir, M.J.K.; Ng, C.A.; Sethupathi, S.; Lim, J.W. A sequential treatment of intermediate tropical landfill leachate using a sequencing batch reactor (SBR) and coagulation. J Environ Manage 2018, 205, 244-252, https://doi.org/10.1016/j.jenvman.2017.09.068.

5. Torretta, V.; Ferronato, N.; Katsoyiannis, I.A.; Tolkou, A.K.; Airoldi, M. Novel and Conventional Technologies for Landfill Leachates Treatment: A Review. Sustainability 2017, 9, https://doi.org/10.3390/su9010009.

6. Propp, V.R.; De Silva, A.O.; Spencer, C.; Brown, S.J.; Catingan, S.D.; Smith, J.E.; Roy, J.W. Organic contaminants of emerging concern in leachate of historic municipal landfills. Environmental Pollution 2021, 276, https://doi.org/10.1016/j.envpol.2021.116474.

7. Masoner, J.R.; Kolpin, D.W.; Furlong, E.T.; Cozzarelli, I.M.; Gray, J.L.; Schwab, E.A. Contaminants of emerging concern in fresh leachate from landfills in the conterminous United States. Environ Sci Process Impacts 2014, 16, 2335-2354, https://doi.org/10.1039/c4em00124a.

8. Chamem, O.; Fellner, J.; Zairi, M. Ammonia inhibition of waste degradation in landfills - A possible consequence of leachate recirculation in arid climates. Waste Manage Res 2020, 38, 1078-1086, https://doi.org/10.1177/0734242X20920945.

9. Baderna, D.; Maggioni, S.; Boriani, E.; Gemma, S.; Molteni, M.; Lombardo, A.; Colombo, A.; Bordonali, S.; Rotella, G.; Lodi, M.; Benfenati, E. A combined approach to investigate the toxicity of an industrial landfill's leachate: Chemical analyses, risk assessment and in vitro assays. Environ Res 2011, 111, 603-613, https://doi.org/10.1016/j.envres.2011.01.015.

10. Li, T.; Li, X.; Chen, J.; Zhang, G.; Wang, H. Treatment of landfill leachate by electrochemical oxidation and anaerobic process. Water Environ Res. 2007, 79, 514-520, https://doi.org/10.2175/106143006X115435.

11. Rekhate, C.V.; Srivastava, J.K. Recent advances in ozone-based advanced oxidation processes for treatment 
of wastewater- A review. Chem Eng J 2020, 3, https://doi.org/10.1016/j.ceja.2020.100031.

12. Asaithambi, P.; Govindarajan, R.; Busier-Yesuf, M.; Selvakumar, P.; Alemayehu, E. Enhanced treatment of landfill leachate wastewater using sono(US)-ozone $\left(\mathrm{O}_{3}\right)$-electrocoagulation(EC) process: role of process parameters on color, COD and electrical energy consumption. Process Saf and Environ Prot 2020, 142, 212 218, https://doi.org/10.1016/j.psep.2020.06.024.

13. Kow, S.H.; Fahmi, M.R.; Abidin, C.Z.A.; Ong, S.A. Advanced Oxidation Processes: Process Mechanisms, Affecting Parameters and Landfill Leachate Treatment. Water Environ 2016, 88, 2047-2058, https://doi.org/10.2175/106143016X14733681695285.

14. Wu, C.; Chen, W.; Gu, Z.; Li, Q. A review of the characteristics of Fenton and ozonation systems in landfill leachate treatment. Sci Total Environ. 2021, 762, https://doi.org/10.1016/j.scitotenv.2020.143131.

15. Kow, S.H.; Fahmi, M.R.; Abidin, C.Z.A.; Ong, S.A.; Ibrahim, A.H.; Sabri, S.N.; Razali, N.A. Oxidation of p-cresol by ozonation. Sains Malaysiana 2018, 47, 1085-1091, https://doi.org/10.17576/jsm-2018-4706-02.

16. Mutseyekwa, M.E.; Doğan, Ş.; Pirgalığlu, S. Ozonation for the removal of bisphenol A. Water Sci Technol 2017, 76, 2764-2775, https://doi.org/10.2166/wst.2017.446.

17. Lian, L.; Yao, B.; Hou, S.; Fang, J.; Yan, S.; Song, W. Kinetic study of hydroxyl and sulfate radical-mediated oxidation of pharmaceuticals in wastewater effluents. Environ Sci Technol 2017, 51, 2954-2962, https://doi.org/10.1021/acs.est.6b05536.

18. Li, W.; Nanaboina, V.; Zhou, Q.; Korshin, G.V. Effects of Fenton treatment on the properties of effluent organic matter and their relationships with the degradation of pharmaceuticals and personal care products. Water Res 2012, 46, 403-412, https://doi.org/10.1016/j.watres.2011.11.002.

19. Lutze, H.V.; Bircher, S.; Rapp, I.; Kerlin, N.; Bakkour, R.; Geisler, M.; von Sonntag, C.; Schmidt, T.C. Degradation of chlorotriazine pesticides by sulfate radicals and influence of organic matter. Enviro Sci Technol 2015, 49, 1673-1680, https://doi.org/10.1021/es503496u.

20. Razali, N.A.; Abidin, C.Z.A.; Ong, S.A.; Fahmi, M.R.; Ibrahim, A.H.; Sabri, S.N.; Kow, S.H. Optimization of ozonation process implemant sodium persulfate using azo dyes. J Adv Res Mater Sci 2018, 46, 10-21.

21. Liu, D.; Feilberg, A.; Adamsen, A.P.S.; Jonassen, K.E.N. The effect of slurry treatment including ozonation on odorant reduction measured by in-situ PTR-MS. Atmos Environ 2011, 45, 3786-3793, https://doi.org/10.1016/j.atmosenv.2011.04.028.

22. Abu-Amr, S.S.; Aziz, H.A.; Adlan, M.N.; Bashir, M.J.K. Pretreatment of stabilized leachate using ozone/persulfate oxidation process. Chem Eng J 2013, 221, 492-499, https://doi.org/10.1016/j.cej.2013.02.038.

23. Wang, Z.; Li, J.; Tan, W.; Wu, X.; Lin, H.; Zhang, H. Removal of COD from landfill leachate by advanced Fenton process combined with electrolysis. Sep Purif 2019, 208, 3-11, https://doi.org/10.1016/j.seppur.2018.06.048.

24. Show, P.L.; Pal, P.; Leong, H.Y.; Juan, J.C.; Ling, T.C. A review on the advanced leachate treatment technologies and their performance comparison: an opportunity to keep the environment safe. Environ Monit Assess 2019, 191, https://doi.org/10.1007/s10661-019-7380-9.

25. Kow, S.H.; Fahmi, M.R.; Abidin, C.Z.A.; Ong, S.A. Mechanistic Insight into the Degradation Pathways of P-cresol in Ozonation, Peroxone, and Ozone-persulfate Process. Ozone Sci Eng 2020, https://doi.org/10.1080/01919512.2020.1846495.

26. Chiang, Y.P.; Liang, Y.Y.; Chang, C.N.; Chao, A.C. Differentiating ozone direct and indirect reactions on decomposition of humic substances. Chemosphere 2006, 65, 2395-2400, https://doi.org/10.1016/j.chemosphere.2006.04.080.

27. Kulikowska, D. Usability of powdered activated carbon for landfill leachate treatment — continued research. Desalin Water Treat 2016, 57, 28560-28569, https://doi.org/10.1080/19443994.2016.1192494.

28. Lovato, M.; Buffelli, J.R.; Abrile, M.; Martín, C. Kinetics and efficiency of ozone for treatment of landfill leachate including the effect of previous microbiological treatment. Environ Sci Pollut Res 2019, 26, 44744487, https://doi.org/10.1007/s11356-018-1710-2.

29. APHA-AWWA-WEF. Standard Methods for the Examination of Water and Wastewater. 20th ed. American Public Health Association, American Water Works Association, Water Environment Federation, Washington DC., 1998.

30. Huang, F.S.; Hung, J.M.; Lu, C.J. Enhanced leachate recirculation and stabilization in a pilot landfill bioreactor in Taiwan. Waste Manag Res 2012, 30, 849-858, https://doi.org/10.1177/0734242X12448515.

31. Sun, N.; Li, X.; Zhan, P.; Hu, F.; Liu, Z. Degradation of leachate biochemical effluents using heat activated persulfate processes: Parameters optimization and removal characteristics of contaminants. Nat Environ Pollut Technol 2018, 17, 555-562.

32. Liu, Z.; Li, X.; Rao, Z.; Hu, F. Treatment of landfill leachate biochemical effluent using the nanoFe3O4/Na2S2O8 system: Oxidation performance, wastewater spectral analysis, and activator characterization. J Environ Manage 2018, 208, 159-168, https://doi.org/10.1016/j.jenvman.2017.12.023.

33. Hoigne, J.; Bader, H. The role of hydroxyl radical reactions in ozonation processes in aqueous solutions. Water Res 1976, 10, 377-386, https://doi.org/10.1016/0043-1354(76)90055-5.

34. Tizaoui, C.; Bouselmi, L.; Mansouri, L.; Ghrabi, A. Landfill leachate treatment with ozone and ozonehydrogen peroxide systems. J Hazard Mater 2007, 140, 316-324, 
https://doi.org/10.1016/j.jhazmat.2006.09.023.

35. Kamenev, I.; Pikkov, L.; Kallas, J. Treatment of landfill leachates: Aerobic bio-oxidation and post-ozonation. In: Proceedings of the Estonian Academy of Sciences, Chemistry. Estonian Academy Publishers, Estonia, Estonia, 2002; pp. 148-155.

36. Vogelpohl, A.; Kim, S.M. Advanced oxidation processes (AOPs) in wastewater treatment. J Ind Eng Chem. 2004, 10, 33-40.

37. Ghazi, N.M.; Lastra, A.A.; Watts, M.J. Hydroxyl radical (.OH ) scavenging in young and mature landfill leachates. Water Res 2014, 56, 148-155, https://doi.org/10.1016/j.watres.2014.03.001.

38. Menzie, C. General color reaction for nitrogen compounds. Anal Chem 1956, 28, 1321-1322, https://doi.org/10.1021/ac60116a028.

39. Pretsch, E.; Bühlmann, P.; Badertscher, M. Structure Determination of Organic Compounds. 4th ed. Springer-Verlag, Berlin Heidelberg, Germany 2009; pp. 1-86, https://doi.org/10.1007/978-3-540-93810-1.

40. Wade, L.G. Organic Chemistry. 8th ed. Pearson, Boston, US, 2013; pp. 346-370.

41. Nanayakkara, N.; Koralage, A.; Meegoda, C.; Kariyawasam, S. Removing nitrogenous compounds from landfill leachate using electrochemical techniques. Environ Eng Res 2019, 24, 339-346, https://doi.org/10.4491/eer.2018.112.

42. Kjeldsen, P.; Barlaz, I.M.A.; Rooker, A.P.; Ledin, A.; Christensen, T.H. Present and long-term composition of MSW landfill leachate: A review. Crit. Rev. Environ Sci Technol 2002, 32, 297-336, https://doi.org/10.1080/10643380290813462.

43. Deng, Y.; Ezyske, C.M. Sulfate radical-advanced oxidation process (SR-AOP) for simultaneous removal of refractory organic contaminants and ammonia in landfill leachate. Water Res 2011, 45, 6189-6194, https://doi.org/10.1016/j.watres.2011.09.015.

44. Abu-Amr, S.; Aziz, H.A.; Bashir, M.; Aziz, S.Q.; Alslaibi, T. Comparison and optimization of ozone-based advanced oxidation processes in the treatment of stabilized landfill leachate. J Eng Res Technol 2015, 2, 122130, https://doi.org/10.13140/RG.2.1.4934.8964.

45. Gani, A.; Wattimena, Y.; Erdiwansyah; Mahidin; Muhibbuddin; Riza, M. Simultaneous sulfur dioxide and mercury removal during low-rank coal combustion by natural zeolite. Heliyon 2021, 7, https://doi.org/10.1016/j.heliyon.2021.e07052.

46. Duan, P.; Pan, J.; Du, W.; Yue, Q.; Gao, B.; Xu, X. Activation of peroxymonosulfate via mediated electron transfer mechanism on single-atom Fe catalyst for effective organic pollutants removal. Appl. Catal. B. 2021, 299, https://doi.org/10.1016/j.apcatb.2021.120714.

47. Carre-Burritt, A.E.; Van Hoomissen, D.J.; Vyas, S. Role of pH in the Transformation of Perfluoroalkyl Carboxylic Acids by Activated Persulfate: Implications from the Determination of Absolute ElectronTransfer Rates and Chemical Computations. Environ. Sci. Technol. 2021, 55, 8928-8936, https://doi.org/10.1021/acs.est.1c02389.

48. Liang, G.; Yang, Z.; Wang, Z.; Cai, X.; Zhang, X.; Xie, X. Relying on the non-radical pathways for selective degradation organic pollutants in $\mathrm{Fe}$ and $\mathrm{Cu}$ co-doped biochar/peroxymonosulfate system: The roles of $\mathrm{Cu}$, Fe, defect sites and ketonic group. Sep. Purif. Technol. 2021, 279, https://doi.org/10.1016/j.seppur.2021.119697.

49. Qin, W.; Lin, Z.; Dong, H.; Yuan, X.; Qiang, Z.; Liu, S.; Xia, D. Kinetic and mechanistic insights into the abatement of clofibric acid by integrated UV/ozone/peroxydisulfate process: A modeling and theoretical study. Water Res. 2020, 186, https://doi.org/10.1016/j.watres.2020.116336.

50. Hu, J.; Chen, H.; Dong, H.; Zhu, L.; Qiang, Z.; Yu, J. Transformation of iopamidol and atrazine by peroxymonosulfate under catalysis of a composite iron corrosion product ( $\mathrm{Fe} / \mathrm{Fe} 3 \mathrm{O} 4)$ : Electron transfer, active species and reaction pathways. J. Hazard. Mater. 2021, 403, https://doi.org/10.1016/j.jhazmat.2020.123553.

51. Liu, Z.; Zhang, G.; Lan, H.; Liu, H.; Qu, J. Optimization of a Hierarchical Porous-Structured Reactor to Mitigate Mass Transport Limitations for Efficient Electrocatalytic Ammonia Oxidation through a ThreeElectron-Transfer Pathway. Environ. Sci. Technol. 2021, 55, 12596-12606, https://doi.org/10.1021/acs.est.1c02825.

52. Guan, C.; Jiang, J.; Pang, S.; Zhou, Y.; Gao, Y.; Li, J.; Wang, Z. Formation and control of bromate in sulfate radical-based oxidation processes for the treatment of waters containing bromide: A critical review. Water Res. 2020, 176, https://doi.org/10.1016/j.watres.2020.115725. 